\title{
Planting Date and Seeding Rate Effects on Sunn Hemp Biomass and Nitrogen Production for a Winter Cover Crop
}

\author{
Kipling S. Balkcom, ${ }^{1}$ Jessica M. Massey, ${ }^{2}$ Jorge A. Mosjidis, ${ }^{2}$ \\ Andrew J. Price, ${ }^{1}$ and Stephen F. Enloe ${ }^{2}$ \\ ${ }^{1}$ USDA-ARS, National Soil Dynamics Laboratory, 411 S. Donahue Drive, Auburn, AL 36832-3439, USA \\ ${ }^{2}$ Department of Agronomy and Soils, Auburn University, 201 Funchess Hall, Auburn, AL 36849-5412, USA
}

Correspondence should be addressed to Kipling S. Balkcom, kip.balkcom@ars.usda.gov

Received 2 May 2011; Accepted 5 July 2011

Academic Editor: Rodomiro Ortiz

Copyright (c) 2011 Kipling S. Balkcom et al. This is an open access article distributed under the Creative Commons Attribution License, which permits unrestricted use, distribution, and reproduction in any medium, provided the original work is properly cited.

\begin{abstract}
Sunn hemp (Crotalaria juncea L.) is a tropical legume that produces plant biomass and nitrogen (N) quickly. Our objectives were to assess the growth of a new sunn hemp cultivar breed to produce seed in a temperate climate and determine the residual $\mathrm{N}$ effect on a rye (Secale cereale L.) cover crop in east-central Alabama from 2007 to 2009. Plant populations, plant height, stem diameter, biomass production, and $\mathrm{N}$ content were determined for two sunn hemp planting dates, following corn (Zea mays L.) and wheat (Triticum aestivum L.) harvest, across different seeding rates (17, 34, 50, and $67 \mathrm{~kg} / \mathrm{ha}$ ). Rye biomass was measured the following spring. Sunn hemp biomass production was inconsistent across planting dates, but did relate to growing degree accumulation. Nitrogen concentrations were inversely related to biomass production, and subsequent $\mathrm{N}$ contents corresponded to biomass levels. Neither planting date nor seeding rate affected rye biomass production, but rye biomass averaged over both planting dates following wheat/sunn hemp averaged $43 \%$ and $33 \%$ greater than rye following fallow. Rye biomass following corn/sunn hemp was equivalent to fallow plots. Early planting dates are recommended for sunn hemp with seeding rates between 17 and $34 \mathrm{~kg} / \mathrm{ha}$ to maximize biomass and $\mathrm{N}$ production.
\end{abstract}

\section{Introduction}

Nitrogen $(\mathrm{N})$ fertilizer costs are volatile and alternative $\mathrm{N}$ sources (such as legumes) are receiving renewed interest. In the southeastern United States, winter annual legumes are commonly incorporated into crop rotations and can contribute considerable biomass and $\mathrm{N}$ during the traditional winter fallow period. Legume biomass production is a major factor determining legume $\mathrm{N}$ contribution [1]. Nitrogen accumulation is highly variable and dependent upon environment, legume selection, planting date, termination, growth stage, and management strategy [1-3]. Throughout the Southeast, warm-season legumes, such as cowpea (Vigna unguiculata L.), sericea lespedeza (Lespedeza cuneata L.), and soybean (Glycine $\max$ L.) are currently available to producers for use as warm season cover crops, but they cannot produce substantial biomass or $\mathrm{N}$ in a short period of time. Sunn hemp, a nontraditional tropical legume, can also be used as a warm season cover crop across the Southeast. "Tropic Sun", the most extensively studied cultivar, has been shown to produce $5.9 \mathrm{Mg} / \mathrm{ha}$ biomass and contribute $134-145 \mathrm{~kg} / \mathrm{ha} \mathrm{N}$ in a $9-12$-week period [4]. This rapid biomass production enables sunn hemp to serve as a summer cover between warm-season harvest and cool-season planting that could also reduce summer fallow weed populations [5], while decomposing biomass $\mathrm{N}$ may supplement $\mathrm{N}$ requirements for a subsequent crop. A winter cover crop, such as rye, could sequester $\mathrm{N}$ produced from decomposing sunn hemp biomass [2]. Late planting dates [6] and low innate fertility of southeastern soils normally limit rye biomass production and subsequent benefits for conservation systems [7]. Typically, commercial $\mathrm{N}$ fertilizer is required to promote maximum biomass production, but this is a difficult expense for growers to justify when the cover crop is not harvested as a marketable product, such as grain production [8]. However, rye is very effective at scavenging 
TABLE 1: Monthly precipitation recorded during each sunn hemp and rye growing season from 2007 to 2009 in east-central Alabama.

\begin{tabular}{|c|c|c|c|c|c|c|c|}
\hline \multicolumn{4}{|c|}{ Sunn hemp growing season precipitation $(\mathrm{mm})^{\mathrm{a}}$} & \multicolumn{4}{|c|}{ Rye growing season precipitation $(\mathrm{mm})^{\mathrm{a}}$} \\
\hline Month & 2007-2008 & 2008-2009 & Average $^{\mathrm{b}}$ & Month & $2007-2008$ & 2008-2009 & Average $^{\mathrm{b}}$ \\
\hline June & 29.2 & 50.3 & 99.1 & Dec. & 94.5 & 82.3 & 93.7 \\
\hline July & 173.2 & 126.2 & 111.1 & Jan. & 110.7 & 52.1 & 95.8 \\
\hline Aug. & 82.8 & 252.0 & 102.1 & Feb. & 101.9 & 105.2 & 91.8 \\
\hline Sep. & 55.9 & 18.8 & 85.1 & Mar. & 77.5 & 243.6 & 146.1 \\
\hline Oct. & 75.4 & 83.1 & 71.3 & Apr. & 100.6 & 109.2 & 97.7 \\
\hline Nov. & 54.6 & 92.7 & 106.9 & & & & \\
\hline Total & 471.2 & 623.1 & 575.7 & Total & 485.1 & 592.3 & 525.0 \\
\hline
\end{tabular}

alabama Mesonet Weather Data.

b 1999-2009 means. Data not available prior to these years.

TABLE 2: Growing degree days measured for sunn hemp during the 2007 and 2008 growing seasons in east-central Alabama.

\begin{tabular}{|c|c|c|c|c|c|c|c|c|}
\hline \multirow{3}{*}{ Month } & \multicolumn{8}{|c|}{ Sunn hemp growing degree days ${ }^{\mathrm{a}}$} \\
\hline & \multicolumn{2}{|c|}{ Wheat 2007} & \multicolumn{2}{|c|}{ Wheat 2008} & \multicolumn{2}{|c|}{ Corn 2007} & \multicolumn{2}{|c|}{ Corn 2008} \\
\hline & $\mathrm{PD} 1^{\mathrm{b}}$ & $\mathrm{PD} 2^{\mathrm{b}}$ & PD1 & $\mathrm{PD} 2$ & PD1 & PD2 & PD1 & PD2 \\
\hline June & 404.4 & 163.3 & 332.5 & 86.7 & & & & \\
\hline July & 544.4 & 544.4 & 538.9 & 538.9 & & & & \\
\hline Aug. & 313.9 & 499.2 & & 359.4 & 295.8 & 18.6 & 163.9 & \\
\hline Sep. & & & & & 458.1 & 458.1 & 439.4 & 369.2 \\
\hline Oct. & & & & & 300.8 & 325.3 & 227.5 & 247.8 \\
\hline Nov. & & & & & & 32.8 & & 17.5 \\
\hline Total & 1262.8 & 1206.9 & 871.4 & 985.0 & 1054.7 & 834.7 & 830.8 & 634.5 \\
\hline
\end{tabular}

${ }^{a}$ GDD until termination. Calculated as [(maximum temp. + minimum temp. $\left.) / 2\right]-10^{\circ} \mathrm{C}$.

${ }^{b}$ Planting date of sunn hemp immediately after cash crop harvest (PD1) and planting date of sunn hemp 2 weeks after cash crop harvest (PD2).

residual soil $\mathrm{N}$ with its extensive root system [9]. Augmenting winter cover crop growth with available $\mathrm{N}$ from sunn hemp biomass could enhance aboveground biomass production and improve associated cover crop benefits, while potentially reducing producer input costs.

"Tropic Sun" cannot produce viable seed in the continental United States except for extreme southern locations of Florida and Texas $[5,10]$; thus, limited production elevates seed prices. Recent Auburn University breeding efforts have produced a new sunn hemp cultivar, "AU Golden", capable of producing viable seed in the Southeast [10]. Furthermore, it is the only sunn hemp cultivar breed for production in temperate environments. As a result, general agronomic information is required to develop broad guidelines for using this legume across the Southeast. Therefore, the study objectives were to (i) assess "AU Golden" performance as a summer cover crop for two different planting dates following corn and wheat harvest across different seeding rates; and (ii) evaluate residual sunn hemp biomass and $\mathrm{N}$ content effects on a cereal rye winter cover crop.

\section{Materials and Methods}

The experiment was conducted from 2007 to 2009 at the Plant Breeding Unit (PBU) near Tallassee, AL on a Wickham sandy loam (fine-loamy, mixed, semiactive, thermic Typic Hapludults). Soil extractable nutrients (P, K, Mg, Ca) ranged from medium to high; $\mathrm{pH}$ was 6.7-7.1. Recommendations from Auburn University Soil Testing Laboratory were followed during the experiment [11].

The experimental design was a randomized complete block with a split-plot treatment restriction in four replicates. Plot dimensions were 2.2 by $6.7 \mathrm{~m}$ (2007-2008) and 2.2 by $10 \mathrm{~m}$ (2008-2009). Smaller experimental plots were used the first year because our seed supply was minimal for the new sunn hemp cultivar. Main plot treatments were sunn hemp planted immediately after cash crop harvest (PD1) or two weeks after cash crop harvest (PD2). The planting dates immediately after harvest of both crops were chosen to maximize the sunn hemp growing season and subsequent benefits associated with sunn hemp. The twoweek interval following the initial planting date was chosen to put some pressure on sunn hemp to see how it would perform with a shorter growing season following corn and in dry, hot growing conditions following wheat. Planting dates following wheat corresponded to 8 June 2007 and 11 June 2008 for PD1 and 22 June 2007 and 26 June 2008 for PD2. Planting dates following corn corresponded to 17 August 2007 and 22 August 2008 for PD1 and 31 August 2007 and 5 September 2008 for PD2. Subplots were seeding rates corresponding to $17,34,50$, and $67 \mathrm{~kg} / \mathrm{ha}$. A Great Plains no-tillage drill (Great Plains Mfg., Salina, KS) set on $18 \mathrm{~cm}$ row spacing seeded sunn hemp into each existing crop residue. The experiment was established following wheat and corn harvest each year. Fall armyworms (FAW) (Spodoptera frugiperda (J.E. Smith)) were discovered on 10 September 
TABLE 3: Sunn hemp population, plant height, and stem diameter for planting date (PD) and seeding rate (SR) planted after wheat and corn harvest during 2007 and 2008 in east-central Alabama.

\begin{tabular}{|c|c|c|c|c|c|c|}
\hline \multirow[b]{2}{*}{ Treatment } & \multicolumn{2}{|c|}{ Population (plant $\left./ \mathrm{m}^{2}\right)$} & \multicolumn{2}{|c|}{ Height $12 \mathrm{WAP}^{\mathrm{a}}(\mathrm{cm})$} & \multicolumn{2}{|c|}{ Stem diameter $(\mathrm{mm})$} \\
\hline & 2007 & 2008 & 2007 & 2008 & 2007 & 2008 \\
\hline \multicolumn{7}{|c|}{ Wheat } \\
\hline \multicolumn{7}{|c|}{ Sunn hemp planting date } \\
\hline $\mathrm{PD}^{\mathrm{b}}$ & 73.8 & 80.5 & 155.2 & 173.3 & 4.84 & 6.61 \\
\hline $\mathrm{PD} 2^{\mathrm{c}}$ & 55.4 & 107.0 & 131.7 & 180.0 & 4.18 & 5.61 \\
\hline $\mathrm{LSD}_{0.05}$ & 21.4 & 19.1 & 10.1 & 16.9 & 0.82 & 0.90 \\
\hline \multicolumn{7}{|c|}{ Sunn hemp seeding rate $(\mathrm{kg} / \mathrm{ha})$} \\
\hline 17 & 31.5 & 46.0 & 145.5 & 172.4 & 4.77 & 6.97 \\
\hline 34 & 53.8 & 66.0 & 141.5 & 174.5 & 4.66 & 6.33 \\
\hline 50 & 77.5 & 102.5 & 149.1 & 183.3 & 4.38 & 6.07 \\
\hline 67 & 95.5 & 160.5 & 138.0 & 176.4 & 4.22 & 5.07 \\
\hline $\mathrm{LSD}_{0.05}$ & 25.0 & 17.0 & 12.2 & 9.1 & 0.76 & 0.89 \\
\hline \multicolumn{7}{|c|}{ Corn } \\
\hline \multicolumn{7}{|c|}{ Sunn hemp planting date } \\
\hline $\mathrm{PD}^{\mathrm{d}}$ & 51.0 & 105.0 & 76.8 & 128.8 & 3.68 & 4.45 \\
\hline $\mathrm{PD} 2^{\mathrm{e}}$ & 27.3 & 100.8 & 93.7 & 128.6 & 3.85 & 4.35 \\
\hline $\mathrm{LSD}_{0.05}$ & 17.3 & 20.4 & 21.7 & 34.3 & 0.71 & 0.72 \\
\hline \multicolumn{7}{|c|}{ Sunn hemp seeding rate $(\mathrm{kg} / \mathrm{ha})$} \\
\hline 17 & 20.5 & 56.5 & 79.5 & 127.3 & 3.68 & 4.96 \\
\hline 34 & 28.0 & 85.0 & 85.7 & 129.0 & 3.94 & 4.48 \\
\hline 50 & 44.0 & 121.5 & 84.3 & 128.7 & 3.65 & 4.23 \\
\hline 67 & 64.0 & 148.5 & 91.5 & 129.7 & 3.77 & 3.94 \\
\hline $\mathrm{LSD}_{0.05}$ & 17.2 & 17.0 & 9.9 & 8.2 & 0.69 & 0.54 \\
\hline \multicolumn{7}{|c|}{ ANOVA $(P>F)$} \\
\hline \multicolumn{7}{|c|}{ Wheat } \\
\hline PD & 0.0781 & 0.0145 & 0.0015 & 0.3461 & 0.0831 & 0.0344 \\
\hline SR & 0.0002 & 0.0000 & 0.2877 & 0.1017 & 0.4230 & 0.0025 \\
\hline $\mathrm{PD} \times \mathrm{SR}$ & 0.7331 & 0.0067 & 0.1650 & 0.0063 & 0.9620 & 0.8520 \\
\hline \multicolumn{7}{|c|}{ Corn } \\
\hline PD & 0.0122 & 0.6108 & 0.0912 & 0.9862 & 0.5620 & 0.7309 \\
\hline SR & 0.0002 & 0.0000 & 0.1201 & 0.9367 & 0.8130 & 0.0068 \\
\hline $\mathrm{PD} \times \mathrm{SR}$ & 0.0591 & 0.0113 & 0.2353 & 0.9438 & 0.3348 & 0.9400 \\
\hline
\end{tabular}

${ }^{\mathrm{a}}$ WAP: weeks after planting.

b Planting date on 8 June 2007 and 11 June 2008.

'Planting date on 22 June 2007 and 26 June 2008.

dPlanting date on 17 August 2007 and 22 August 2008.

eplanting date on 31 August 2007 and 5 September 2008.

2007 in PD1 plots following corn. An insecticide application of Karate $8 \mathrm{Z}$ (lambda-cyhalothrin) did not prevent FAW leaf defoliation during early growth stages, which likely affected experimental results in 2007 by lowering biomass potential.

Sunn hemp populations were measured 4 weeks after planting (WAP) by counting all emerged sunn hemp in one $0.25 \mathrm{~m}^{2}$ quadrant from each plot. At $12 \mathrm{WAP}$, final plant heights and stem diameters $0.33 \mathrm{~m}$ aboveground were measured in each plot from 10 random plants. Aboveground sunn hemp biomass was also randomly collected from two $0.25 \mathrm{~m}^{2}$ quadrants 12 WAP. Plants were terminated at $50 \%$ bloom stage by applying glyphosate (N-(phosphonomethyl) glycine), a cheap, systemic, nonselective herbicide that is popular in the region, to ensure adequate termination and prevent seed production. Plant biomass was dried in a forced air oven at $55^{\circ} \mathrm{C}$ for $72 \mathrm{~h}$, weighed, and ground using Wiley (Thomas Scientific, Swedesboro, NJ) followed by cyclone (UDY Corp., Fort Collins, CO) sample mills to pass a $1 \mathrm{~mm}$ screen. A LECO TruSpec CN analyzer (LECO Corp., St. Joseph, MI) measured total carbon (C) and N. Sunn hemp $\mathrm{N}$ content was the product of average biomass $(\mathrm{kg} / \mathrm{ha})$ and average total $\mathrm{N}$ concentration $(\mathrm{g} / \mathrm{kg})$.

Planting equipment used for sunn hemp also seeded "Elbon" rye at $101 \mathrm{~kg} / \mathrm{ha}$ into standing terminated sunn hemp residue for both previous crop phases on 13 November 2007 and 10 November 2008. Additional rye was drilled into alleys ( 8.7 by $10 \mathrm{~m}$ (2007-2008), 8.7 by $13.3 \mathrm{~m}$ (20082009)) adjacent to each test location that served as controls 
TABLE 4: Sunn hemp biomass yield, $N$ concentration, and $N$ content for planting date (PD) and seeding rate (SR) when planted after wheat harvest and corn harvest during 2007 and 2008 in east-central Alabama.

\begin{tabular}{|c|c|c|c|c|c|c|}
\hline \multirow[b]{2}{*}{ Treatment } & \multicolumn{2}{|c|}{ Biomass yield (Mg/ha) } & \multicolumn{2}{|c|}{$N$ concentration $(\mathrm{g} / \mathrm{kg})$} & \multicolumn{2}{|c|}{$N$ content $(\mathrm{kg} / \mathrm{ha})$} \\
\hline & 2007 & 2008 & 2007 & 2008 & 2007 & 2008 \\
\hline \multicolumn{7}{|c|}{ Wheat } \\
\hline \multicolumn{7}{|c|}{ Planting date } \\
\hline$P D 1^{\mathrm{a}}$ & 4.0 & 4.5 & 15.6 & 26.5 & 62.9 & 116.7 \\
\hline $\mathrm{PD} 2^{\mathrm{b}}$ & 2.0 & 6.6 & 11.5 & 13.8 & 21.5 & 90.7 \\
\hline $\mathrm{LSD}_{0.05}$ & 1.0 & 1.0 & 5.7 & 5.1 & 15.7 & 40.8 \\
\hline \multicolumn{7}{|c|}{ Seeding rate $(\mathrm{kg} / \mathrm{ha})$} \\
\hline 17 & 2.5 & 5.6 & 13.6 & 20.6 & 35.7 & 107.1 \\
\hline 34 & 2.9 & 5.5 & 13.9 & 20.5 & 43.3 & 104.3 \\
\hline 50 & 3.2 & 5.8 & 13.4 & 19.0 & 44.7 & 101.9 \\
\hline 67 & 3.2 & 5.4 & 13.4 & 20.5 & 45.0 & 101.5 \\
\hline $\mathrm{LSD}_{0.05}$ & 0.9 & 1.4 & 3.5 & 7.1 & 22.3 & 36.8 \\
\hline \multicolumn{7}{|c|}{ Corn } \\
\hline \multicolumn{7}{|c|}{ Planting date } \\
\hline $\mathrm{PD} 1^{\mathrm{c}}$ & 0.8 & 3.2 & 35.4 & 16.8 & 27.6 & 48.9 \\
\hline $\mathrm{PD} 2^{\mathrm{d}}$ & 1.6 & 3.3 & 25.8 & 17.0 & 40.3 & 52.7 \\
\hline $\mathrm{LSD}_{0.05}$ & 0.7 & 2.7 & 3.7 & 7.0 & 19.8 & 26.1 \\
\hline \multicolumn{7}{|c|}{ Seeding rate $(\mathrm{kg} / \mathrm{ha})$} \\
\hline 17 & 1.2 & 3.1 & 31.3 & 17.6 & 35.0 & 47.0 \\
\hline 34 & 1.3 & 3.7 & 29.6 & 17.4 & 36.6 & 64.3 \\
\hline 50 & 0.9 & 3.4 & 28.8 & 16.9 & 25.1 & 46.9 \\
\hline 67 & 1.3 & 3.0 & 32.7 & 15.9 & 39.2 & 44.8 \\
\hline $\mathrm{LSD}_{0.05}$ & 0.3 & 1.0 & 5.2 & 4.6 & 10.1 & 17.5 \\
\hline \multicolumn{7}{|c|}{ ANOVA $(P>F)$} \\
\hline \multicolumn{7}{|c|}{ Wheat } \\
\hline PD & 0.0026 & 0.0002 & 0.1291 & 0.0000 & 0.0000 & 0.1701 \\
\hline SR & 0.3701 & 0.9363 & 0.9884 & 0.9587 & 0.8055 & 0.9873 \\
\hline $\mathrm{PD} \times \mathrm{SR}$ & 0.5462 & 0.9598 & 0.4831 & 0.9853 & 0.9219 & 0.8714 \\
\hline \multicolumn{7}{|c|}{ Corn } \\
\hline PD & 0.0261 & 0.9289 & 0.0000 & 0.9344 & 0.1664 & 0.7334 \\
\hline SR & 0.0286 & 0.4183 & 0.4260 & 0.8693 & 0.0447 & 0.1025 \\
\hline $\mathrm{PD} \times \mathrm{SR}$ & 0.0169 & 0.2708 & 0.7515 & 0.6596 & 0.2085 & 0.2750 \\
\hline
\end{tabular}

${ }^{a}$ Planting date on 8 June 2007 and 11 June 2008.

${ }^{b}$ Planting date on 22 June 2007 and 26 June 2008.

${ }^{c}$ Planting date on 17 August 2007 and 22 August 2008.

dPlanting date on 31 August 2007 and 5 September 2008.

to estimate rye production without sunn hemp. Prior to rye establishment, fifteen soil cores $(2.5 \mathrm{~cm}$ diam. $)$ were randomly collected from the surface $15 \mathrm{~cm}$ of each plot. Soils were dried at $105^{\circ} \mathrm{C}$ for $24 \mathrm{~h}$ in a forced air oven and sieved with a $2 \mathrm{~mm}$ screen. Initial ammonium $\left(\mathrm{NH}_{4}-\mathrm{N}\right)$ and nitrate $\left(\mathrm{NO}_{3}-\mathrm{N}\right)$ concentrations were determined colorimetrically with a microplate reader [12]. Aboveground rye biomass was randomly measured from two $0.25 \mathrm{~m}^{2}$ quadrants in each plot and four different sections of each control area on 11 April 2008 and 23 April 2009. These dates correspond to typical termination dates for a rye cover crop preceding summer cash crop planting for the Southeast. Biomass samples were processed as previously described for sunn hemp biomass.
Data were analyzed by previous crop and year using SAS (SAS Institute Inc., Cary, NC) MIXED procedure. Replication $\times$ planting date was random, while planting date, seeding rate, and interactions were fixed. Protected least significant differences compared treatment means when significant $F$-tests $(P \leq 0.05)$ were observed among measured traits.

\section{Results and Discussion}

Weather data records were unavailable prior to 1999 at the experimental location, so a $10-\mathrm{yr}$ average was used to 
TABLE 5: Rye biomass yield and sunn hemp biomass carbon to nitrogen ratio for planting date (PD) and seeding rate (SR) when planted after wheat and corn harvest during 2007 and 2008 in east-central Alabama.

\begin{tabular}{|c|c|c|c|c|}
\hline \multirow[b]{2}{*}{ Treatment } & \multicolumn{2}{|c|}{ Rye biomass yield (Mg/ha) } & \multicolumn{2}{|c|}{ Sunn hemp C: N ratio } \\
\hline & 2008 & 2009 & 2007 & 2008 \\
\hline \multicolumn{5}{|c|}{ Wheat-sunn hemp } \\
\hline \multicolumn{5}{|c|}{ Sunn hemp planting date } \\
\hline $\mathrm{PD} 1^{\mathrm{a}}$ & 2.2 & 6.5 & 31.2 & 18.3 \\
\hline $\mathrm{PD} 2^{\mathrm{b}}$ & 2.1 & 8.4 & 41.0 & 36.4 \\
\hline $\mathrm{LSD}_{0.05}$ & 1.2 & 2.4 & 16.4 & 8.0 \\
\hline \multicolumn{5}{|c|}{ Sunn hemp seeding rate (kg/ha) } \\
\hline 17 & 2.2 & 6.8 & 38.2 & 26.3 \\
\hline 34 & 2.4 & 7.3 & 34.8 & 27.6 \\
\hline 50 & 2.0 & 8.3 & 35.7 & 28.5 \\
\hline 67 & 2.1 & 7.3 & 35.7 & 27.2 \\
\hline $\mathrm{LSD}_{0.05}$ & 0.59 & 1.7 & 11.3 & 11.2 \\
\hline Control $^{\mathrm{c}}$ & 1.5 & 5.6 & & \\
\hline \multicolumn{5}{|c|}{ Corn-sunn hemp } \\
\hline \multicolumn{5}{|c|}{ Sunn hemp planting date } \\
\hline$P D 1^{d}$ & 2.0 & 3.3 & 12.6 & 30.5 \\
\hline $\mathrm{PD} 2^{\mathrm{e}}$ & 2.3 & 3.3 & 17.9 & 29.3 \\
\hline $\mathrm{LSD}_{0.05}$ & 0.6 & 2.3 & 2.0 & 14.7 \\
\hline \multicolumn{5}{|c|}{ Sunn hemp seeding rate $(\mathrm{kg} / \mathrm{ha})$} \\
\hline 17 & 2.5 & 3.7 & 15.0 & 29.9 \\
\hline 34 & 1.9 & 3.7 & 15.6 & 26.8 \\
\hline 50 & 2.1 & 3.1 & 16.0 & 33.2 \\
\hline 67 & 2.1 & 2.7 & 14.2 & 29.8 \\
\hline $\mathrm{LSD}_{0.05}$ & 0.78 & 1.1 & 2.8 & 9.6 \\
\hline Control $^{\mathrm{c}}$ & 2.3 & 3.2 & & \\
\hline \multicolumn{5}{|c|}{ ANOVA $(P>F)$} \\
\hline \multicolumn{5}{|c|}{ Wheat-sunn hemp } \\
\hline $\mathrm{PD}$ & 0.7237 & 0.1038 & 0.1947 & 0.0001 \\
\hline SR & 0.6203 & 0.3554 & 0.9311 & 0.9825 \\
\hline $\mathrm{PD} \times \mathrm{SR}$ & 0.8267 & 0.9734 & 0.4776 & 0.8164 \\
\hline \multicolumn{5}{|c|}{ Corn-Sunn hemp } \\
\hline PD & 0.2901 & 0.9597 & 0.0000 & 0.8359 \\
\hline SR & 0.5952 & 0.1594 & 0.5733 & 0.5913 \\
\hline $\mathrm{PD} \times \mathrm{SR}$ & 0.5709 & 0.0537 & 0.8235 & 0.9360 \\
\hline
\end{tabular}

${ }^{a}$ Planting date on 8 June 2007 and 11 June 2008.

bPlanting date on 22 June 2007 and 26 June 2008.

'Samples collected from fallow areas and not included in statistics.

${ }^{d}$ Planting date on 17 August 2007 and 22 August 2008.

eplanting date on 31 August 2007 and 5 September 2008.

estimate a "normal" growing season (AWIS Weather Services, Inc., Auburn, AL). On average, the site received below average precipitation during the 2007 sunn hemp growing season, while the 2008 growing season received greater than average rainfall, especially during August (Table 1). Sunn hemp growing degree days (GDDs) were calculated monthly, until the crop was terminated. In general, sunn hemp GDD accumulation was greater during the 2007 growing season compared to 2008 (Table 2).

3.1. Sunn Hemp following Wheat. Planting date did not affect plant populations measured 4 WAP, but plant populations increased as seeding rates increased during the 2007 growing season (Table 3). In 2008, plant populations were greater two weeks after cash crop harvest compared to immediately after cash crop harvest, while higher seeding rates resulted in higher observed plant populations (Table 3). Populations were greater in 2008 than 2007 (Table 3) and that was attributed to increased early season precipitation in 2008 (Table 1).

Sunn hemp planted immediately after wheat harvest was $18 \%$ taller 12 WAP compared to PD2 in 2007 (Table 3). In 2008 , an interaction $(P>F=0.0063)$ was observed between planting date and seeding rate for heights measured 12 WAP (Table 3). Plant heights were greater for PD2, except at the $50 \mathrm{~kg} / \mathrm{ha}$ seeding rate. Stem diameter was thicker for PD1 
across the 2008 growing season (Table 3). Stem diameter also decreased as seeding rates increased in 2008 (Table 3). These results were similar to findings from a previous study that examined sunn hemp growth [13].

In 2007, there was 50\% more sunn hemp biomass produced for PD1 compared to PD2 (Table 4). However, $47 \%$ more biomass was measured for PD2 compared to PD1 in 2008 (Table 4). The differences in biomass production between planting dates and growing seasons can be explained by the difference in GDD accumulation. Growing degree day accumulation was greater for PD1 in 2007, but in 2008, GDD accumulation was greater for PD2 (Table 2). Sunn hemp N concentration was not affected by planting date or seeding rate in 2007, but planting date did affect $\mathrm{N}$ concentration in 2008. In 2008, $N$ concentration was $92 \%$ greater following PD1 than for PD2 (Table 4). The highest $\mathrm{N}$ concentration corresponded to the lowest plant biomass measured during that year, which may have corresponded to a simple dilution effect of the $\mathrm{N}$ concentration. The corresponding $\mathrm{N}$ contents were only affected by planting date in 2007 (Table 4). The $\mathrm{N}$ content measured from PD2 was 66\% lower compared to the $\mathrm{N}$ content from PD1 (Table 4 ). The difference can be primarily attributed to the difference in biomass levels between PD1 and PD2 during the 2007 growing season. In addition, the lower biomass levels produced in 2007 corresponded to low $\mathrm{N}$ content values compared with 2008 $\mathrm{N}$ content levels.

3.2. Sunn Hemp following Corn. Plant populations measured 4 WAP were affected by planting date in 2007, but no difference was observed in 2008 (Table 3). The first planting date resulted in $87 \%$ more emerged plants compared to PD2. Despite no differences observed between planting dates in 2008, the number of emerged plants were much greater compared to the 2007 growing season (Table 3 ). Seeding rate affected emerged plants during both years with an increase in emerged plants as seeding rate increased (Table 3). However, an interaction was observed in both growing seasons between seeding rate and planting date. The interaction can be attributed to the inconsistent response of emerged plants within seeding rates across the planting dates (data not shown). Final plant heights measured 12 WAP were not affected by planting date or seeding rate during either growing season (Table 3). In 2007, stem diameter was not affected by planting date or seeding rate, but in 2008, stem diameter decreased as seeding rate increased (Table 3 ). Sunn hemp biomass measured following PD2 was twice the biomass amounts measured following PD1 in 2007 (Table 4). However, reduced PD1 biomass yields were affected by FAW damage. The FAW damage reduced biomass levels that also affected treatments randomly. The later planted sunn hemp received less FAW damage. As a result, an interaction was observed between planting date and seeding rate that has no agronomic importance (Table 4). In 2008, no differences were observed between sunn hemp biomass levels across planting dates or seeding rates (Table 4). Average sunn hemp biomass levels were lower following corn than biomass levels previously reported for “Tropic Sun”. “Tropic Sunn” biomass amounts were reported as $4.4-6.8 \mathrm{Mg} / \mathrm{ha}$ in Georgia [14], 4.5 Mg/ha in Florida [3], and 4.6-6.0 Mg/ha in Alabama [4]. The later sunn hemp planting dates following corn reduced biomass levels compared to levels observed following wheat. The greatest GDD accumulation for sunn hemp following corn was observed in 2007 (Table 2), but this coincided with FAW damage.

Sunn hemp $\mathrm{N}$ concentration was only affected by planting date in 2007 and corresponded to a $37 \%$ increase for PD1 compared to PD2 (Table 4). Similar to N concentrations following wheat, the lowest plant biomass corresponded to the highest $\mathrm{N}$ concentration. Sunn hemp N content was only affected by seeding rate during the 2007 growing season (Table 4). The major difference among seeding rates was related to a very low biomass level for one seeding rate that was confounded with the FAW pressure that year. Sunn hemp $\mathrm{N}$ content following corn was lower compared to other studies across the Southeast, but those studies used a different sunn hemp cultivar [2-4].

3.3. Sunn Hemp Effect on Rye. Precipitation received from December 2007 to April 2008 was similar to the 10-year average, except for the month of April (Table 1). The amount of rainfall recorded was approximately half the amount usually received. The amount of rainfall received during the 2008-2009 growing season exceeded the 10 year average (Table 1). This increase can be attributed to a much wetter March, despite lesser rainfall amounts recorded in December and January compared to the average (Table 1). Inorganic $\mathrm{N}$ concentrations were low prior to rye establishment for both growing seasons. Soils averaged $1.9 \mathrm{mg} / \mathrm{kg} \mathrm{NH} \mathrm{NH}_{4}-\mathrm{N}$ and $2.7 \mathrm{mg} / \mathrm{kg} \mathrm{NO}_{3}-\mathrm{N}$ for the 2007-2008 growing season and $5.7 \mathrm{mg} / \mathrm{kg} \mathrm{NH}_{4}-\mathrm{N}$ and $7.3 \mathrm{mg} / \mathrm{kg} \mathrm{NO}_{3}-\mathrm{N}$ for the $2008-$ 2009 growing season. Although rye may have used the initial inorganic $\mathrm{N}$ present in the soil, the $\mathrm{N}$ concentrations observed were much lower than $\mathrm{N}$ concentrations and subsequent $\mathrm{N}$ content values available from sunn hemp residue (Table 4 ).

Sunn hemp planting date or seeding rate following wheat or corn showed no effect on rye biomass production in 2008 (Table 5). However, rye biomass following wheat/sunn hemp, averaged over both planting dates, was $43 \%$ greater than rye biomass following fallow plots (Table 5 ). In contrast, rye biomass following corn/sunn hemp planting dates was equivalent to the control plots (Table 5 ). Rye biomass produced during the 2009 growing season was also not affected by planting date or seeding rate following wheat/sunn hemp, but rye biomass averaged over both planting dates was 33\% greater compared to following fallow plots (Table 5). Similar to the previous growing season, rye biomass following corn/sunn hemp planting dates was equivalent to fallow plots, but rye biomass production was increased compared to 2008 (Table 5). The increase in rye biomass observed during 2009 corresponds with increased inorganic N levels present in the soil, but also coincides with increased sunn hemp biomass levels (Table 4). Similar rye biomass yields 
were reported in other studies across the Southeast [15] and Midwest [16, 17].

Planting sunn hemp immediately after cash crop harvest maximized sunn hemp biomass production. Previous studies also indicated that delayed planting reduced sunn hemp biomass production $[13,18]$. However, an interaction between planting date and seeding rate was observed for rye biomass following corn/sunn hemp in 2009 (Table 5). The interaction can be attributed to inconsistent differences in rye biomass levels between the two lowest seeding rates across planting dates (data not shown). The $\mathrm{C}: \mathrm{N}$ ratio of sunn hemp biomass is a predictor for the availability of $\mathrm{N}$ contained in residue for crops following sunn hemp termination. Low ratios (i.e., $<20$ to 1 ) result in net $\mathrm{N}$ mineralization, while high ratios (i.e., $>30$ to 1 ) result in net immobilization of $\mathrm{N}$ [19]. The $\mathrm{C}: \mathrm{N}$ ratio of sunn hemp was only affected by planting date for sunn hemp following corn in 2007 and sunn hemp following wheat in 2008 (Table 5). In both cases, the $\mathrm{C}: \mathrm{N}$ ratio was lower for PD1. These lower $\mathrm{C}: \mathrm{N}$ ratios can be attributed to low biomass levels and high $\mathrm{N}$ concentrations for PD1 (Table 4). Despite low C: N ratios indicating increased $\mathrm{N}$ mineralization, no differences in rye biomass production could be linked to sunn hemp $\mathrm{C}: \mathrm{N}$ ratios. Rye was planted after sunn hemp began losing leaves, which contain considerable $\mathrm{N}$ and subsequently decompose quickly due to low $\mathrm{C}: \mathrm{N}$ ratios [4]. Leaves can account for $10-15 \%$ of biomass [20], but leaf contribution was not accounted for before biomass collection. Despite not accounting for leaf contribution, rye is an excellent scavengern of residual $\mathrm{N}$ [9], but rye biomass levels indicate leaf $\mathrm{N}$ concentration was minimal in this experiment.

\section{Conclusions}

Growing degree days affected sunn hemp biomass production and subsequent $\mathrm{N}$ contents; higher biomass levels were produced following wheat compared to corn. Seeding rates appeared to have a minimal effect on biomass production, regardless of planting date, which indicated the lower seeding rates $(17-34 \mathrm{~kg} / \mathrm{ha})$ are adequate, thus reducing seed cost. Rye biomass averaged $43 \%$ and $33 \%$ greater than rye following fallow for both planting dates in the wheat/sunn hemp system. However, rye following sunn hemp in the corn system did not result in increased biomass levels compared to fallow plots. Lower sunn hemp biomass levels following corn can be attributed to less GDD accumulation, although biomass levels following corn in 2008 were much greater than 2007 levels that were reduced by FAW damage. The $\mathrm{N}$ production from decomposing sunn hemp biomass utilized in certain crop rotations combined with additional advantages, such as erosion control and potential SOM accumulation, can benefit southeastern producers that utilize winter cover crops.

\section{Acknowledgments}

The authors would like to recognize the Alabama Wheat and Feed Grain Commission for their support of this research.
The authors would also like to acknowledge the assistance provided by Jeffrey Walker, Agronomic Technician, USDAARS, Steve Nightengale, Superintendent, Plant Breeding Unit, Auburn University, and Shawn Scott, former Assistant Superintendent, Plant Breeding Unit, Auburn University. The support provided by this organization and individuals was invaluable to the success of this project. In addition, this publication is based upon work supported by the Agricultural Research Service. Mention of trade names or proprietary products does not indicate endorsement by USDA or Auburn University and does not imply its approval to the exclusion of other products that may be suitable.

\section{References}

[1] J. F. Holderbaum, A. M. Decker, J. J. Meisinger, F. R. Mulford, and L. R. Vough, "Fall-seeded legume cover crops for notillage corn in the humid East," Agronomy Journal, vol. 82, no. 1, pp. 117-124, 1990.

[2] K. S. Balkcom and D. W. Reeves, "Sunn-hemp utilized as a legume cover crop for corn production," Agronomy Journal, vol. 97, no. 1, pp. 26-31, 2005.

[3] C. M. Cherr, J. M. S. Scholberg, and R. McSorley, "Green manure approaches to crop production: a synthesis," Agronomy Journal, vol. 98, no. 2, pp. 302-319, 2006.

[4] Z. Mansoer, D. W. Reeves, and C. W. Wood, "Suitability of sunn hemp as an alternative late-summer legume cover crop," Soil Science Society of America Journal, vol. 61, no. 1, pp. 246253, 1997.

[5] J. A. Mosjidis and G. Wehtje, "Weed control in sunn hemp and its ability to suppress weed growth," Crop Protection, vol. 30, no. 1, pp. 70-73, 2011.

[6] P. J. Bauer and D. W. Reeves, "A comparison of winter cereal species and planting dates as residue cover for cotton grown with conservation tillage," Crop Science, vol. 39, no. 6, pp. 1824-1830, 1999.

[7] K. Balkcom, H. Schomberg, W. Reeves et al., "Managing cover crops in conservation tillage systems," in Managing Cover Crops Profitably, A. Clark, Ed., pp. 44-61, Sustainable Agriculture Network, Beltsville, Md, USA, 3rd edition, 2007.

[8] K. S. Balkcom, C. W. Wood, J. F. Adams, and B. Meso, "Suitability of peanut residue as a nitrogen source for a rye cover crop," Scientia Agricola, vol. 64, no. 2, pp. 181-186, 2007.

[9] S. M. Dabney, J. A. Delgado, and D. W. Reeves, "Using winter cover crops to improve soil and water quality," Communications in Soil Science and Plant Analysis, vol. 37, no. 7-8, pp. 1221-1250, 2001.

[10] J. A. Mosjidis, "Breeding of annual and perennial legumes and their utilization as forage and crops," Field and Vegetable Crops Research, vol. 44, no. 2, pp. 7-11, 2007.

[11] J. F. Adams, C. C. Mitchell, and H. H. Bryant, Soil Test Fertilizer Recommendations for Alabama Crops, vol. 178 of Agronomy and Soils Department, Alabama Agricultural Experiment Station, Auburn, Ala, USA, 1994.

[12] G. K. Sims, T. R. Ellsworth, and R. L. Mulvaney, "Microscale determination of inorganic nitrogen in water and soil extracts," Communications in Soil Science and Plant Analysis, vol. 26, no. 1-2, pp. 303-316, 1995.

[13] C. G. Cook, A. W. Scott, and P. Chow, "Planting date and cultivar effects on growth and stalk yield of sunn hemp," Industrial Crops and Products, vol. 8, no. 2, pp. 89-95, 1998. 
[14] H. H. Schomberg, N. L. Martini, J. C. Diaz-Perez, S. C. Phatak, K. S. Balkcom, and H. L. Bhardwaj, "Potential for using sunn hemp as a source of biomass and nitrogen for the Piedmont and Coastal Plain regions of the Southeastern USA," Agronomy Journal, vol. 99, no. 6, pp. 1448-1457, 2007.

[15] J. D. Vaughan and G. K. Evanylo, "Soil nitrogen dynamics in winter cover crop-corn systems," Communications in Soil Science and Plant Analysis, vol. 30, no. 1-2, pp. 31-52, 1999.

[16] J. J. O. Odhiambo and A. A. Bomke, "Grass and legume cover crop effects on dry matter and nitrogen accumulation," Agronomy Journal, vol. 93, no. 2, pp. 299-307, 2001.

[17] M. L. Ruffo, D. G. Bullock, and G. A. Bollero, "Soybean yield as affected by biomass and nitrogen uptake of cereal rye in winter cover crop rotations," Agronomy Journal, vol. 96, no. 3, pp. 800-805, 2004.

[18] G. White and J. Haun, "Growing crotalaria juncea, a multipurpose legume, for paper pulp," Economic Botany, vol. 19, no. 2, pp. 175-183, 1965.

[19] S. L. Tisdale, W. L. Nelson, J. D. Beaton, and J. L. Havlin, Soil Fertility and Fertilizers, Macmillan, New York, NY, USA, 5th edition, 1993.

[20] A. J. Marshall, R. N. Gallaher, K. H. Wang, and R. McSorley, "Partitioning of dry matter and minerals in sunn hemp," in Proceedings of the 25th Annual Southern Conservation Tillage Conference for Sustainable Agriculture, E. van Santen, Ed., pp. 310-313, Alabama Agricultural Experiment Station and Auburn University, Auburn, Ala, USA, June 2002. 


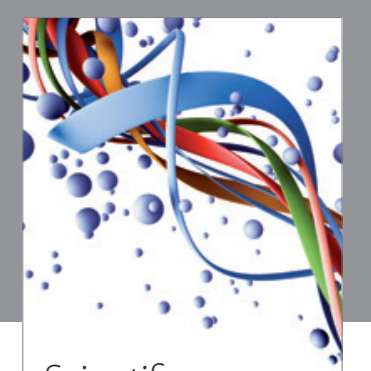

Scientifica
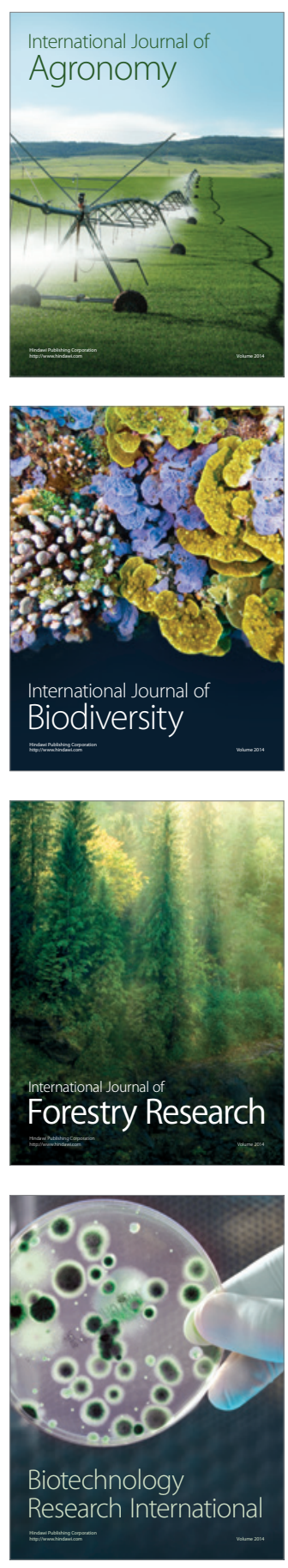
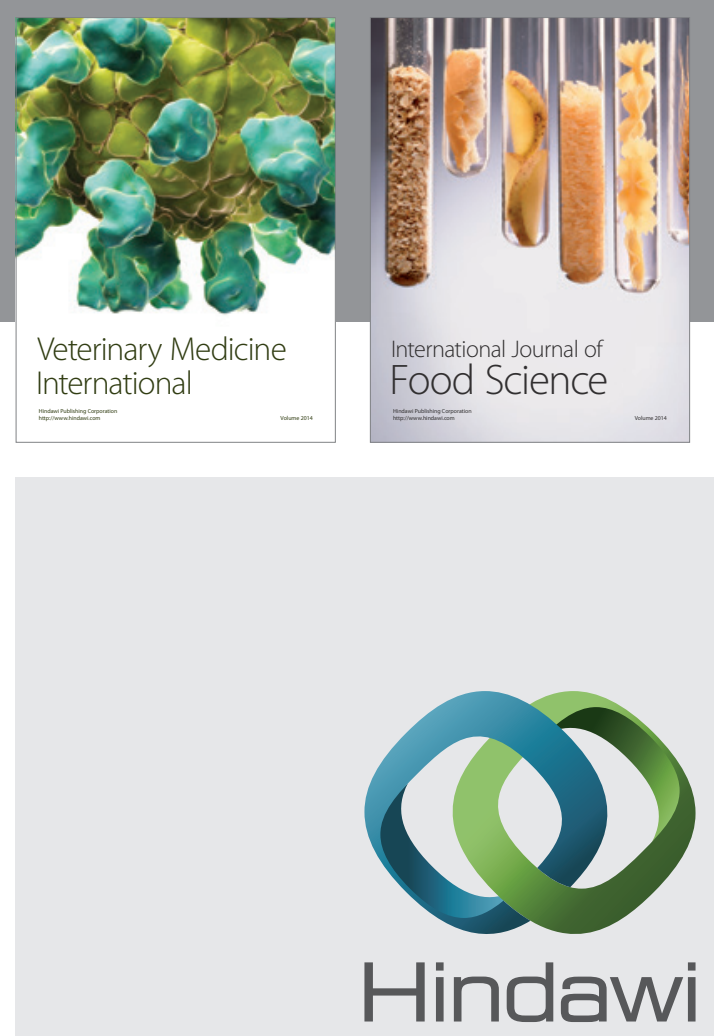

Submit your manuscripts at

http://www.hindawi.com
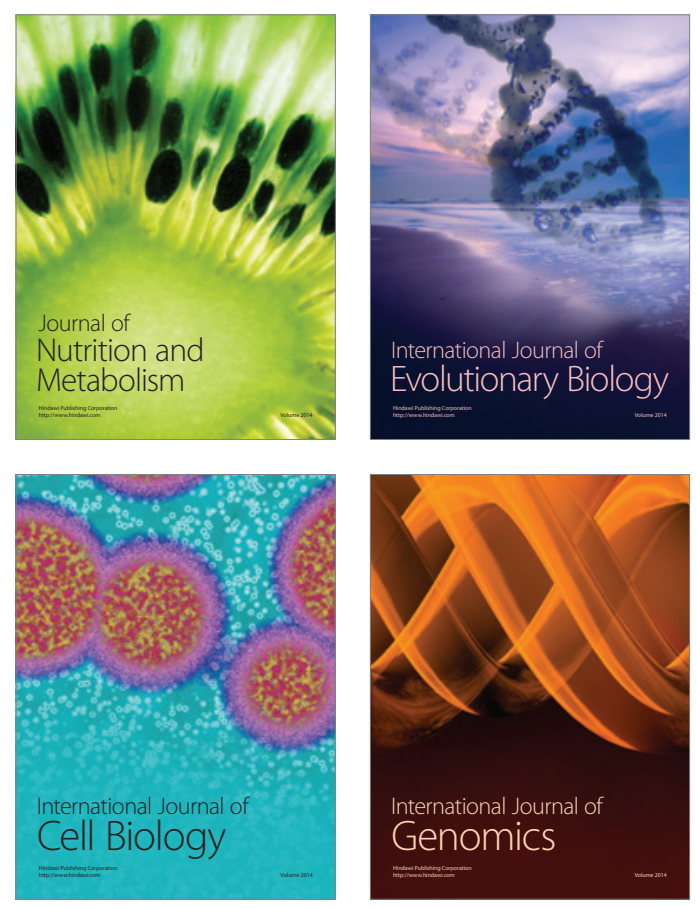
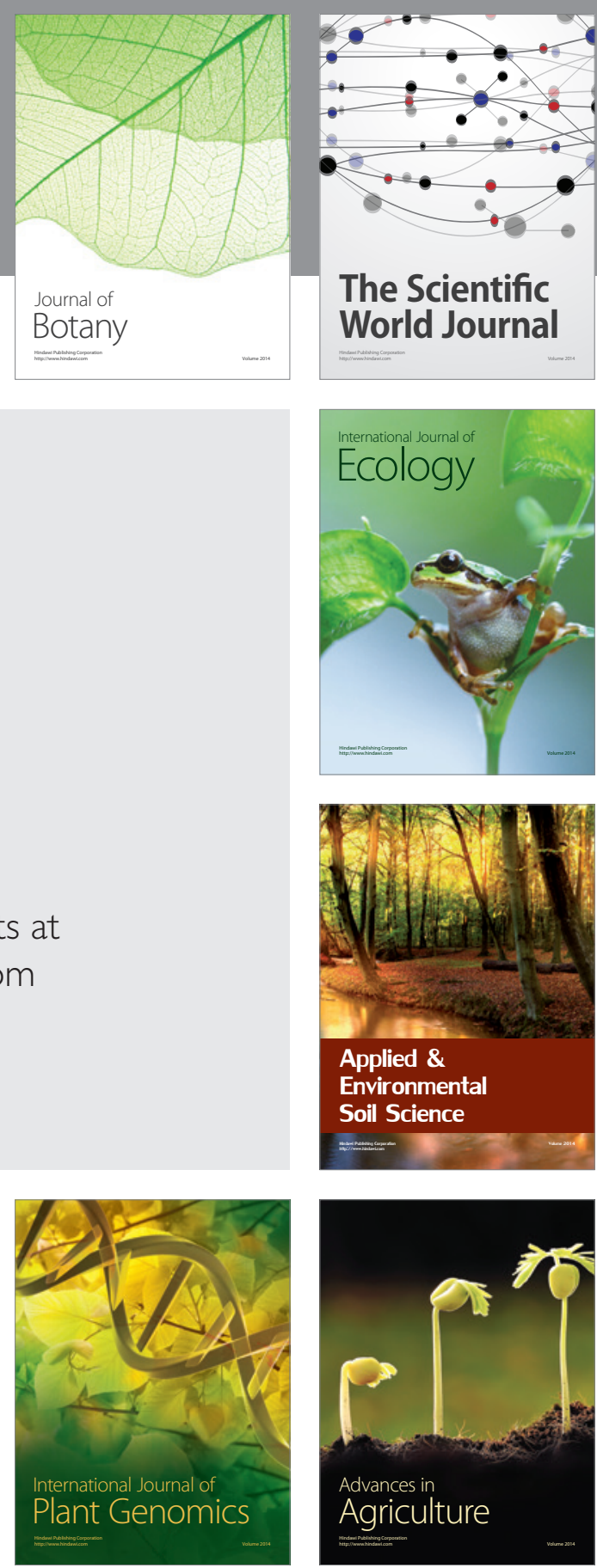

The Scientific World Journal
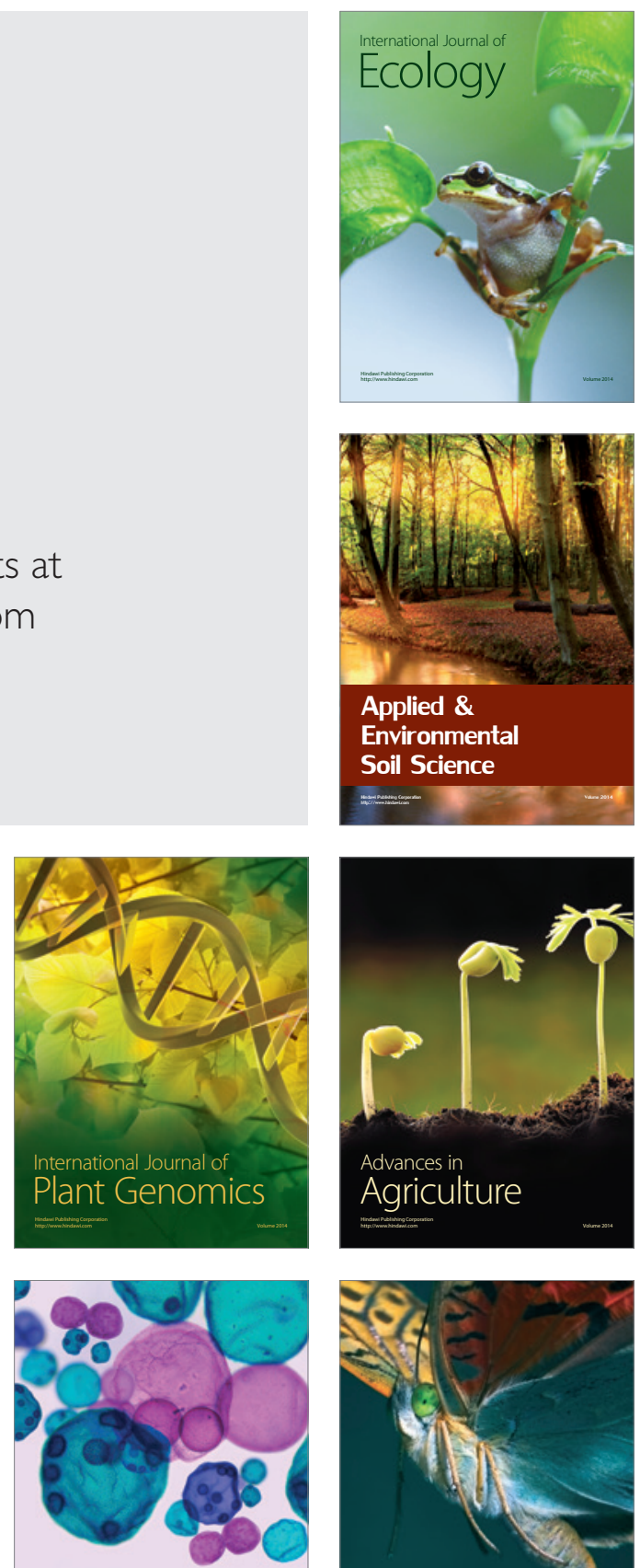

International Journal of Microbiology

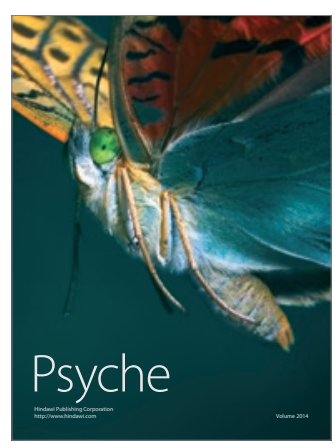

